\title{
Policy or poverty trap? Attitude of goat farmers towards the conservation rule on goat rearing in Bhutan
}

\author{
Kesang Wangchuk ${ }^{1 *}$, Mindu $^{2}$, Thukten ${ }^{3}$ and Sonam Wangchuk ${ }^{2}$
}

\begin{abstract}
The study objectives were to gather feedback and opinions of goat farmers on the Forest and Nature Conservation Rule on goat rearing in Bhutan and identify field constraints arising from the conservation rule. Focus group and individual farmer survey methods were employed, and a semi-structured questionnaire was used to interview 180 goat farmers of six districts. All respondents were aware of the conservation rule. Majority of respondents knew goats as a threat to forest and crops. The vast majority of respondents felt that the conservation rule is not relevant in modern times, and all respondents felt the need to revise the rule. The main problem faced by farmers was difficulty in maintaining their goat numbers to four. The other problems faced were frequent conflicts with Forest personnel and restricted opportunities to earn more income. While the expected changes in the conservation rule included provisions to allow a farmer to rear more number of goats under stall-fed conditions, the additional rule suggested by farmers was allowing goats to browse freely in the forest. Majority of farmers reared goats under stall-fed conditions. The most common practice of managing goat populations was selling goats to fellow farmers. Despite the constraints, a majority of farmers expressed their willingness to continue goat rearing in the future, mainly to generate more income. The study findings suggest revision of the rule on goat rearing, with strong consideration of the needs of the modern farming system and growing economic demands. In revising the rule, the study recommends balanced representation from stakeholders and technical experts from both forest and livestock disciplines.
\end{abstract}

Keywords: Conservation rules, Forest, Goats, Income generation, Policy, Stall-feeding

\section{Background}

Policy is often understood as a strategy or an action by an institution to address a given problem. Government policies to modernize agriculture and protect forests are widespread in Southeast Asia and have caused profound changes in the regions' agricultural system (Jakobsen et al. 2007; Wangchuk et al. 2014). In the least developed countries, several policy interventions provide assurances to the farming communities of long-term benefits and sustainability of natural resources. However, policies incompatible with the interests of farming communities have had a negative impact on developmental programmes (Wallner et al. 2007). Jakobsen et al. (2007)

\footnotetext{
* Correspondence: kesangwangchuk@rocketmail.com

${ }^{1}$ Research and Extension Division, Department of Livestock, Ministry of Agriculture and Forests, Thimphu, Bhutan

Full list of author information is available at the end of the article
}

draw attention to a typical case in Vietnam where the implementation of the land tenure policy of the Vietnamese government has increased the forest cover at the expense of agricultural production and low agriculture productivity is linked to rural poverty (Mukadasi and Lusiba 2006). The policy lapses suggest that for policy interventions to succeed in rural areas, there is a vital need to achieve compatibility between policy objectives and aspirations of rural inhabitants.

Rule Number 70 of the Forest and Nature Conservation Rules of Bhutan 2006 clearly mentions goat rearing as a threat to normal forest health (MoAF 2006), in spite of the fact that no scientific studies were conducted to quantify the severity of damage to vegetation by goats. The notion of goats as a threat to the environment arises mainly from experiences drawn in other countries (Sparts 
and Mueller-Dombois 1973; Bayne et al. 2003; Vuren 1992). As a measure to regulate the goat population, the rule allows only Bhutanese citizens to rear goats. Further, the rule prohibits each household from rearing more than four goats which must be strictly under tethered and stall-fed conditions. As per this conservation rule, any farmer violating the rule is liable to a penalty of ngultrum (Bhutanese currency) 10.00 per goat per day (1 US $\$=67$ ngultrums). For nonBhutanese farmers, an additional penalty includes confiscation of goats. The conservation rule is enforced by the territorial forest offices spread across the country under the Department of Forests.

Although the conservation rules were amended and revised thrice in 2000, 2003, and 2006, the rule on goat rearing received less attention and therefore remains unrevised to date. Restriction of goat numbers under stall-fed and tethered conditions raises questions about the practicality of the rule under rural situations. Especially, goats are prolific breeders and multiply within a few years, which puts farmers in a difficult situation to manage the goat population. The non-revision of the rule on goat rearing over the last two decades indicates that the rule does not consider field realities. This is primarily because the Forest and Nature Conservation Rules are not based on any research studies (Wangdi et al. 2013). The stringent rule reflects the fact that the rule was formulated largely from the forest managers' perspectives, overlooking the implications on the livelihood of farmers who depend on livestock. Thus, the rule appears biased and is a major hurdle for farmers who have the resources and interests to increase their goat flock sizes. In light of the government's efforts to boost the rural economy and the consequent shift in practices from subsistence to commercial farming, there is a need to investigate the practicality of this conservation rule on goat farming in the current times. In this paper, we focus on farmers' attitude towards the Forest and Nature Conservation Rule on goat rearing in Bhutan and the changes farmers wish to see in the rule. Therefore, the study objectives were to gather feedback and opinions of goat farmers on the rule on goat rearing and identify field constraints arising from this conservation rule.

\section{Study area}

The study was conducted in the winter of 2015 in selected districts of Sarpang, Tsirang, Dagana, Chukha, Samdrup Jongkhar, and Samtse (Figure 1), where goat farming is practised on a larger scale than other districts. We sampled these districts since they fall within southern Bhutan and most southern Bhutanese are of Nepalese origin who have a strong tradition of goat rearing. Therefore, these districts were reliable sources of information for the study. Livestock is an important source of milk, meat, manure, and draught power for the households, who rear goats along with other livestock. Goats are used for meat, manure, and milk. Especially, chevon (goat meat) is a delicacy

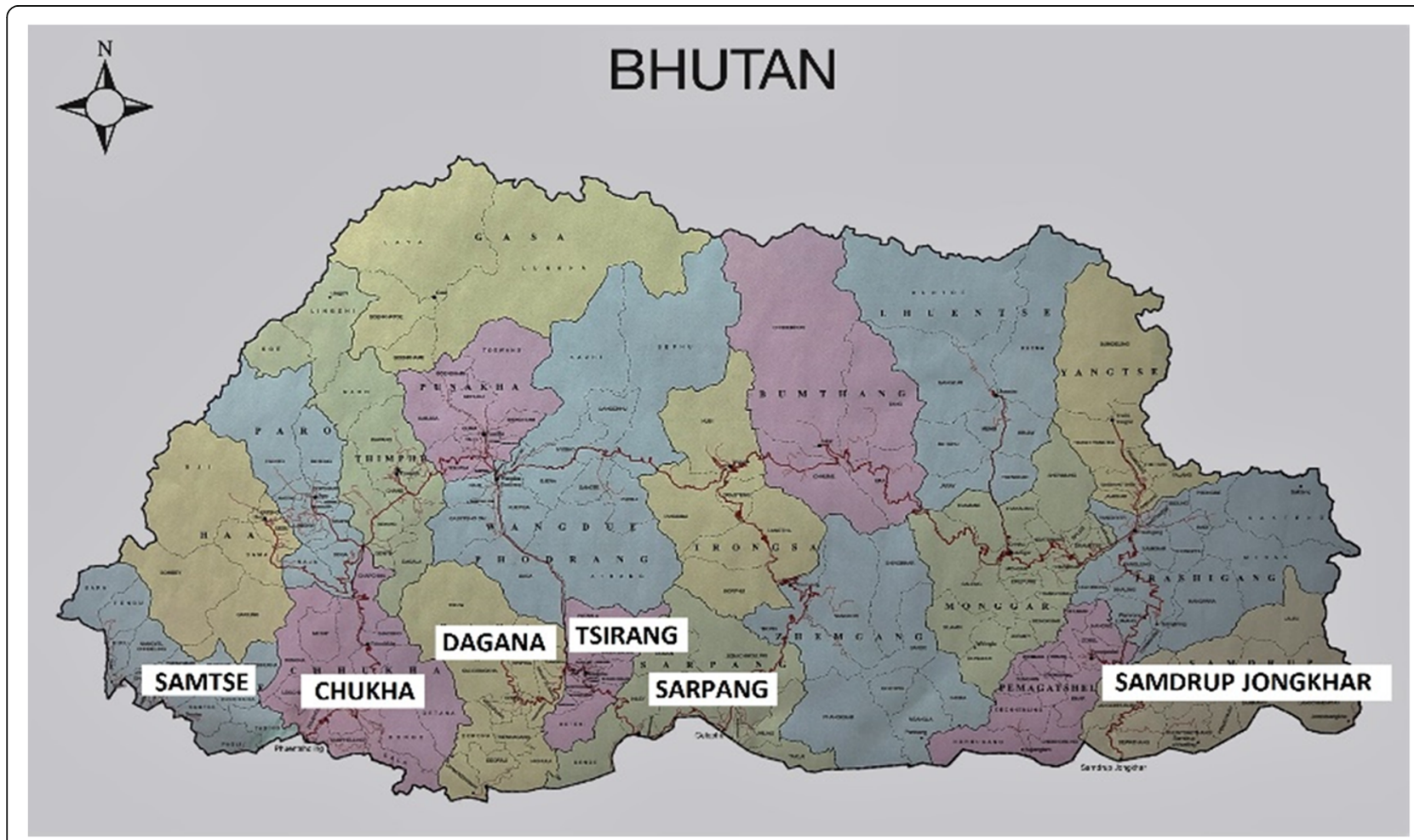

Figure 1 Six major goat-rearing districts as sites for the field survey 
served during a religious festival of southern Bhutanese. The average number of goats in each sampled village household was about 5 . The average herd size per household in different districts including the study area is shown in Table 1. Livestock farming in rural Bhutan is subsistence and low input-based.

The climates of the study districts are hot and humid subtropical. Average summer temperature is $30^{\circ} \mathrm{C}$ from June to September, and average winter temperature is $15^{\circ} \mathrm{C}$ from November to March. Average rainfall is about $390 \mathrm{~mm}$ in summer and $50 \mathrm{~mm}$ in winter. The elevation ranges from $170 \mathrm{~m}$ in the south to $2,350 \mathrm{~m}$ in the north. The forest cover ranges from $78 \%$ to $87 \%$ compared with other land uses, and the forest type is mainly broadleaf (MoAF 2010). The terrain is generally rugged, and large areas are commonly cultivated with crops such as rice, areca nut (the astringent seed of an areca palm, which is often chewed with betel leaves), and mandarin.

\section{Methods}

\section{Sampling technique}

Two techniques were used for selecting administrative blocks and villages within each district. For selecting villages and respondents, we employed the snowball sampling technique at two stages. In the first stage, the livestock statistics for 2015 (Department of Livestock 2015) were referred so as to identify key administrative blocks with the largest goat populations. In the second stage, researchers, development workers, and local government bodies were consulted who provided a list of villages which would be the main sources of information on goat farming. In each district, only one key village with the largest goat population was selected. Therefore, six villages in six districts were selected for the field surveys. Local leaders recommended households and village elders as potential respondents of survey interviews.

\section{Sampling and field interviews}

The number of households in each of the six villages ranged from 45 to 54. All households reared livestock, including goats. From the total households, only 30 were selected from each village based on their experience with goat rearing and information provided by the local leaders. A total of 180 goat farmers from six districts were interviewed, using a semi-structured questionnaire. The selection criteria included the following: the farmer should be a permanent resident of the village, be

Table 1 Population of livestock species in study area compared with other districts. Figures inside the cells represent the total livestock population in different districts and mean herd size per household in each district

\begin{tabular}{|c|c|c|c|c|c|c|c|c|c|c|c|c|c|c|c|c|}
\hline \multirow[b]{2}{*}{ District } & \multicolumn{8}{|c|}{ Total population per district } & \multicolumn{8}{|c|}{ Mean herd size per household in each district } \\
\hline & Cattle & Mithun $^{a}$ & Yak & Buffalo & Equine & Pig & Sheep & Goat & Cattle & Mithun $^{a}$ & Yak & Buffalo & Equine & Pig & Sheep & Goat \\
\hline Bumthang & 10977 & 9 & 3621 & 0 & 1278 & 0 & 694 & 5 & 9 & 1 & 3 & 0 & 1 & 0 & 1 & 0 \\
\hline Chhukhab $^{\mathrm{b}}$ & 21207 & 91 & 0 & 4 & 569 & 1435 & 620 & 5779 & 6 & 1 & 0 & 0 & 1 & 1 & 1 & 1 \\
\hline Dagana $^{b}$ & 7127 & 29 & 0 & 78 & 379 & 1781 & 267 & 7182 & 6 & 1 & 0 & 0 & 1 & 1 & 1 & 1 \\
\hline Gasa & 977 & 0 & 6314 & 0 & 2268 & 0 & 3 & 34 & 2 & 0 & 13 & 0 & 5 & 0 & 0 & 0 \\
\hline Haa & 9730 & 0 & 4458 & 0 & 1081 & 75 & 1 & 10 & 9 & 0 & 4 & 0 & 1 & 1 & 0 & 0 \\
\hline Lhuentse & 13616 & 20 & 316 & 0 & 1463 & 138 & 103 & 59 & 8 & 1 & 1 & 0 & 1 & 1 & 0 & 0 \\
\hline Monggar & 26367 & 38 & 0 & 0 & 1465 & 1065 & 8 & 65 & 6 & 1 & 0 & 0 & 1 & 1 & 0 & 0 \\
\hline Paro & 12246 & 28 & 3360 & 0 & 1408 & 568 & 10 & 662 & 5 & 0 & 1 & 0 & 1 & 1 & 0 & 1 \\
\hline Pemagatshel & 7834 & 5 & 0 & 0 & 459 & 540 & 6 & 78 & 3 & 0 & 0 & 0 & 1 & 1 & 0 & 0 \\
\hline Punakha & 12153 & 4 & 0 & 0 & 461 & 254 & 19 & 233 & 6 & 0 & 0 & 0 & 1 & 1 & 0 & 3 \\
\hline SamdrupJongkhar ${ }^{\mathrm{b}}$ & 16741 & 128 & 5 & 15 & 1155 & 460 & 57 & 1442 & 5 & 0 & 0 & 1 & 1 & 1 & 0 & 1 \\
\hline Samtse ${ }^{b}$ & 31295 & 15 & 0 & 258 & 300 & 1977 & 5246 & 13237 & 5 & 1 & 0 & 0 & 1 & 1 & 1 & 1 \\
\hline Sarpang ${ }^{b}$ & 23968 & 109 & 0 & 76 & 497 & 2879 & 607 & 4327 & 7 & 1 & 0 & 0 & 1 & 1 & 1 & 1 \\
\hline Thimphu & 3526 & 2 & 10005 & 0 & 1410 & 370 & 2 & 47 & 4 & 0 & 11 & 0 & 2 & 1 & 0 & 0 \\
\hline Trashigang & 27284 & 66 & 6202 & 0 & 2712 & 529 & 2756 & 257 & 5 & 0 & 1 & 0 & 1 & 1 & 1 & 1 \\
\hline Trashiyangtse & 10955 & 10 & 555 & 0 & 1184 & 259 & 2 & 192 & 5 & 0 & 1 & 0 & 1 & 1 & 0 & 1 \\
\hline Trongsa & 11315 & 4 & 85 & 0 & 388 & 75 & 107 & 91 & 9 & 0 & 1 & 0 & 1 & 0 & 1 & 0 \\
\hline Tsirang $^{b}$ & 12482 & 2 & 0 & 155 & 115 & 1805 & 224 & 7771 & 4 & 0 & 0 & 0 & 0 & 1 & 1 & 1 \\
\hline WangduePhodrang & 22149 & 16 & 3301 & 0 & 596 & 726 & 676 & 450 & 8 & 0 & 1 & 0 & 1 & 1 & 1 & 4 \\
\hline Zhemgang & 10795 & 166 & 0 & 0 & 1065 & 791 & 2 & 62 & 7 & 0 & 0 & 0 & 1 & 1 & 0 & 0 \\
\hline
\end{tabular}

${ }^{a}$ The mithun (Bos frontalis) is a large semi-domesticated bovine, considered as a descendent of the wild Indian gaur or bison, distributed in Northeast India, Bangladesh, northern Burma and in Yunnan, China. ${ }^{b}$ Study districts 
engaged actively in goat farming for several years, have witnessed issues and constraints of goat farming, and be willing to cooperate with the interviewer. The survey was administered through questionnaires with openand close-ended questions.

The two survey methods were used for gathering information: focus groups and individual farmer surveys. In the focus group survey, the groups were requested to provide their awareness and opinions on the Forest and Nature Conservation Rules. Questions were also asked on whether the respondents were comfortable with the rule on goat rearing. If uncomfortable, they were requested to suggest solutions to address the issue. For the individual farmer survey, questions were divided into six parts. The first part of the questionnaire focussed on the farmer's background including education background, number of milking cows, total agricultural land, area under pasture cultivation, major crop, and the main sources of income. The second part included questions that were aimed at obtaining details of goat rearing such as number and type of goats, purpose of goat rearing, number of goats slaughtered annually, number of goats sold across the border with India, and contribution of goats to rural livelihood. The fourth and fifth parts concentrated on feeding and herd management, respectively. The final part of the questionnaire was on whether a farmer was interested to continue rearing goats in the future. Accordingly, farmers were asked to provide reasons for continuing or discontinuing goat rearing in the future. Information missed by the questionnaire was captured through informal interviews and discussions during tea breaks and mealtimes after survey interviews. Informal discussions and interviews lasted from $30 \mathrm{~min}$ to one hour.

During the entire survey, to simplify information, we used a three-point Likert scale (Likert 1932) against the commonly used five-point scale, since reliability and validity of information was found to be independent of the scale points employed by Likert-type items (Jacoby and Matell 1971). The scale was used to gather information on whether the informants agreed, disagreed, or did not have answers to questions related to the conservation rule.

\section{Data analysis}

Data were subjected to descriptive analysis using SPSS 22 (Landau and Everitt 2004). Farmers' opinions were displayed in percentages.

\section{Results}

Farmers' awareness and opinions on the Forest and Nature Conservation Rule

Farmers' awareness and opinions on the Forest and Nature Conservation Rule on goat rearing and its relevance in modern times are presented in Table 2. All respondents were aware of the conservation rule. While
Table 2 Farmers' awareness and opinions on the Forest and Nature Conservation Rule on goat rearing and its relevance in modern times

\begin{tabular}{|c|c|c|c|}
\hline \multirow[t]{2}{*}{ Survey question } & \multicolumn{3}{|c|}{ Respondents (\%) } \\
\hline & Yes & No & $\begin{array}{l}\text { Do not } \\
\text { know }\end{array}$ \\
\hline $\begin{array}{l}\text { Are you aware of the Forest and Nature } \\
\text { Conservation Rule on goat rearing? }\end{array}$ & 100 & 0 & 0 \\
\hline Do you know why the rule was imposed? & 60 & 40 & 0 \\
\hline $\begin{array}{l}\text { The reason for imposing the conservation } \\
\text { rule is goats cause destruction to crops } \\
\text { and forest due to over browsing. }\end{array}$ & 60 & 0 & 40 \\
\hline $\begin{array}{l}\text { Is the conservation rule relevant at the } \\
\text { present time? }\end{array}$ & 20 & 80 & 0 \\
\hline $\begin{array}{l}\text { Is it necessary to revise the conservation } \\
\text { rule? }\end{array}$ & 100 & 0 & 0 \\
\hline
\end{tabular}

$60 \%$ of respondents knew the reason behind imposing the rule, the remaining $40 \%$ did not know the reason. The respondents who knew the reason mentioned that goats cause destruction to forest and crops due to excessive browsing. However, the vast majority of respondents felt that the conservation rule is not relevant in the present time, and all respondents felt it necessary to revise the rule according to the changing times.

\section{Field problems caused by the conservation rule and farmers' opinions}

Table 3 presents the field problems and farmers' opinions on the conservation rule. The main problem faced by farmers was difficulty in maintaining their goat flocks to four. The other problems faced were frequent conflicts with forest personnel and restricted opportunities to earn more income. As a consequence, the problems resulted in farmers being unhappy with the rule. About half of the respondents mentioned restricted income generation as the main reason for being unhappy while the other half did not know why they were unhappy with the rule. Restricted opportunity to earn more income was also featured as the main reason for the conservation rule being impractical at the present time. The rule was also mentioned as an obstacle to livestock development.

According to the majority of respondents, the rule needed revision and the expected changes in the revised rule included allowing farmers to rear more goats, followed by free grazing in the forest. Majority of the respondents felt that an additional rule is needed to restrict goat numbers under free browsing in the forest. Respondents also felt the need for an additional rule allowing farmers to rear more number of goats under stall-fed conditions. However, on the future support to goat rearing, the respondents expected the government to provide materials for fencing and constructing goat sheds. 
Table 3 Field problems caused by the conservation rule and farmers' opinions

\begin{tabular}{|c|c|c|}
\hline Survey question & Farmers' opinions & $\begin{array}{l}\text { Respondents } \\
(\%)\end{array}$ \\
\hline \multirow{3}{*}{$\begin{array}{l}\text { What are the field problems } \\
\text { caused by the conservation } \\
\text { rule? }\end{array}$} & $\begin{array}{l}\text { Difficulty in maintaining } \\
\text { goat number to four }\end{array}$ & 60 \\
\hline & $\begin{array}{l}\text { Conflict with forest } \\
\text { personnel }\end{array}$ & 20 \\
\hline & $\begin{array}{l}\text { Restricted opportunity } \\
\text { to earn more income }\end{array}$ & 20 \\
\hline \multirow{6}{*}{$\begin{array}{l}\text { What are the reasons for } \\
\text { being unhappy with the } \\
\text { rule? }\end{array}$} & $\begin{array}{l}\text { Rule restricts income } \\
\text { generation }\end{array}$ & 40 \\
\hline & $\begin{array}{l}\text { Goat population is difficult } \\
\text { to manage }\end{array}$ & 20 \\
\hline & Do not know & 40 \\
\hline & $\begin{array}{l}\text { Rule restricts opportunities } \\
\text { to earn more income }\end{array}$ & 60 \\
\hline & $\begin{array}{l}\text { Rule is an obstacle to } \\
\text { livestock development }\end{array}$ & 20 \\
\hline & Do not know & 20 \\
\hline \multirow[t]{2}{*}{$\begin{array}{l}\text { What changes would you } \\
\text { like to see in the rule? }\end{array}$} & $\begin{array}{l}\text { Rule allowing a farmer to } \\
\text { rear more number of goats }\end{array}$ & 80 \\
\hline & $\begin{array}{l}\text { Rule allowing free grazing } \\
\text { in forest }\end{array}$ & 20 \\
\hline \multirow[t]{2}{*}{$\begin{array}{l}\text { What additional rules would } \\
\text { you suggest on goat } \\
\text { rearing? }\end{array}$} & $\begin{array}{l}\text { Rule restricting number of } \\
\text { goats under free browsing } \\
\text { in the forest }\end{array}$ & 60 \\
\hline & $\begin{array}{l}\text { Rule allowing unlimited } \\
\text { number of goats under } \\
\text { stall-feeding }\end{array}$ & 40 \\
\hline \multirow{3}{*}{$\begin{array}{l}\text { What government } \\
\text { interventions and support } \\
\text { do you expect on goat } \\
\text { rearing? }\end{array}$} & $\begin{array}{l}\text { Materials to fence and } \\
\text { construct goat sheds for } \\
\text { stall-feeding }\end{array}$ & 40 \\
\hline & $\begin{array}{l}\text { Improvement of goat } \\
\text { breeds }\end{array}$ & 40 \\
\hline & $\begin{array}{l}\text { Supply of forage planting } \\
\text { materials }\end{array}$ & 20 \\
\hline
\end{tabular}

Types of feeding management and practices of managing goat population

Stall-feeding was the most common type of feeding management practised by the majority of farmers (Figure 2). Practices to manage goat populations were selling goats to fellow farmers, slaughtering prematurely, retaining in herds, selling as well as retaining goats in herd, and selling and slaughtering prematurely (Table 4). Of the five practices, selling goats to fellow farmers was mentioned by the majority of respondents as the most common practice.

\section{Future of goat rearing}

The majority of respondents wanted to continue rearing goats in the future (Figure 3). Their reasons were income generation (main reason), manure production, and easy management of goats (Table 5).

\section{Discussion}

The threat of goats to vegetation is not unique to Bhutan. This is also a potential threat in other parts of the globe. For example, goats have been reported to cause damage to vegetation and soil in Hawaii (Sparts and Mueller-Dombois 1973), Australia (Bayne et al. 2003), and New Zealand (Vuren 1992). A large number of plant species are palatable to goats, and they have an ability to browse and graze in inaccessible areas (Henzell 1993; Parkes et al. 1996). Goats also survive under adverse environmental conditions due to their ability to survive on low-nutrient fibrous vegetation (Wilson and Mulham 1980; Doyle et al. 1984). These characteristics make goats a potential threat to vegetation and the environment.

The findings of our study show that goat farmers are fully aware of the Government's conservation rule and the reason for having it in place. This probably explains why the majority of farmers comply with the rule and rear goats under stall-fed conditions. It may also reflect the farmers' concern that goats could cause destruction to forested vegetation. Several methods adopted by farmers to manage goat numbers also demonstrate their efforts to comply with the rule. However, the farmers' strong disagreement on the relevance of the conservation rule currently suggests a series of constraints facing goat rearing. These constraints are probably the main reason for all the surveyed goat farmers to stress the urgent need to revise the rule. Goat farmers in the study area are generally resource-poor, and the stringent conservation rule on only rearing up to four goats per household is a major hurdle to farmers earning higher incomes and generating better employment opportunities.

Since this conservation rule was not based on research (Wangdi et al. 2013), there is no scientific basis and explanation as to why the number of goats permitted per household was fixed to four. According to the conversion factor used for converting animals into livestock units in Bhutan, an adult goat is equated to 0.10 livestock units (LU) (Dorji 1993). In the subtropical region of Bhutan, the livestock carrying capacity is estimated at $5 \mathrm{LU} \mathrm{ha}^{-1}$. Thus, under free grazing, 1-ha land could support about 50 adult goats. According to Tamang et al. (2008), each household rears about five goats in the subtropical region; therefore, 1-ha land is estimated to support the goats belonging to about 10 households. It is important that these estimated figures are taken into account in the revision of the conservation rule in the future, in addition to making the rule simpler to fit into the current farming system.

The findings of the study reveal that the farmers are overall dissatisfied with the conservation rule on goat rearing. The study highlights lack of responsiveness of 


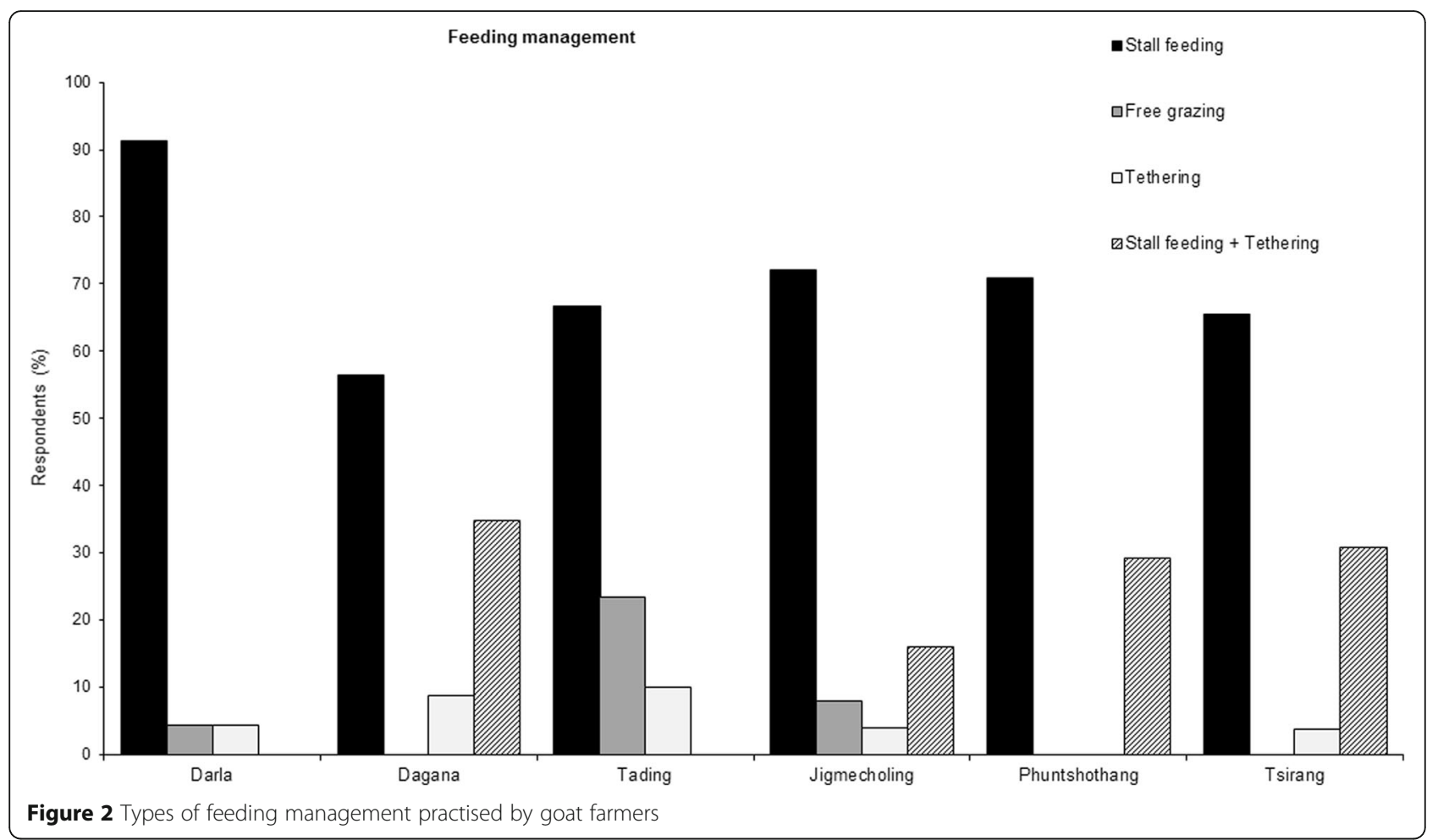

the policy objectives to the needs of goat farmers; this is attributable to rules being formulated largely from forest managers' perspectives. The study also indicates that the policy-making process lacked proper consultations with stakeholders and balanced representation by technical experts from required disciplines. Thus, there is a need to take onboard the livestock personnel and technocrats, particularly in the revision and formulation of rules involving livestock.

The low popularity of the conservation rule is due to three major constraints that it causes: restricted opportunities to earn more income, difficulty in managing goat population growth, and conflicts with forest personnel. These constraints have persisted for decades, yet they failed to draw the attention of policy-makers when the conservation rules were revised in 2000, 2003, and 2006. Further, the lack of proper evaluation of the conservation rule and its impracticality for livestock farmers seems to have contributed to the constraints. Therefore, it is not surprising to see farmers expecting changes in the rule as well as suggesting additional rules in favour of goat farming. The rule may have been successful in achieving the conservation objectives but has not benefitted the goat farmers. The rule has not considered the human factor, which is vital to the success of any policy. This is probably the main reason why agriculture policies in Bhutan have often failed to bring about significant growth for the poorest after almost 55 years of planned development (Rural Livelihood Project Phase 2014). Failure to recognize the interest of resource-poor farmers leads to failure in policy (Bird 2008; Rocha MA: Testing the DFID state-building framework: Case study on Angola and Mozambique, unpublished). Our findings suggest that, as long as the conservation objectives and aspirations of goat farmers are not compatible, the conservation rule is likely to come under criticism and generate public debates.

Table 4 Practices followed by farmers to manage goat population

\begin{tabular}{|c|c|c|c|c|c|}
\hline Study site & Sell off to fellow farmer & Slaughter prematurely & Retain in herd & $\begin{array}{l}\text { Sell off to fellow farmer + } \\
\text { retain in herd }\end{array}$ & $\begin{array}{l}\text { Sell off to fellow farmer + } \\
\text { slaughter prematurely }\end{array}$ \\
\hline Darla & 77.3 & 4.50 & 13.6 & 4.50 & - \\
\hline Dagana & 70.7 & 8.2 & - & 20.8 & - \\
\hline Tading & 100.00 & - & - & - & - \\
\hline Jigmecholing & 60.7 & 3.60 & 32.1 & 3.6 & - \\
\hline Phuntshothang & 42.3 & 7.70 & 7.70 & 11.5 & 30.8 \\
\hline Tsirang & 50.0 & - & - & 19.2 & 30.8 \\
\hline
\end{tabular}




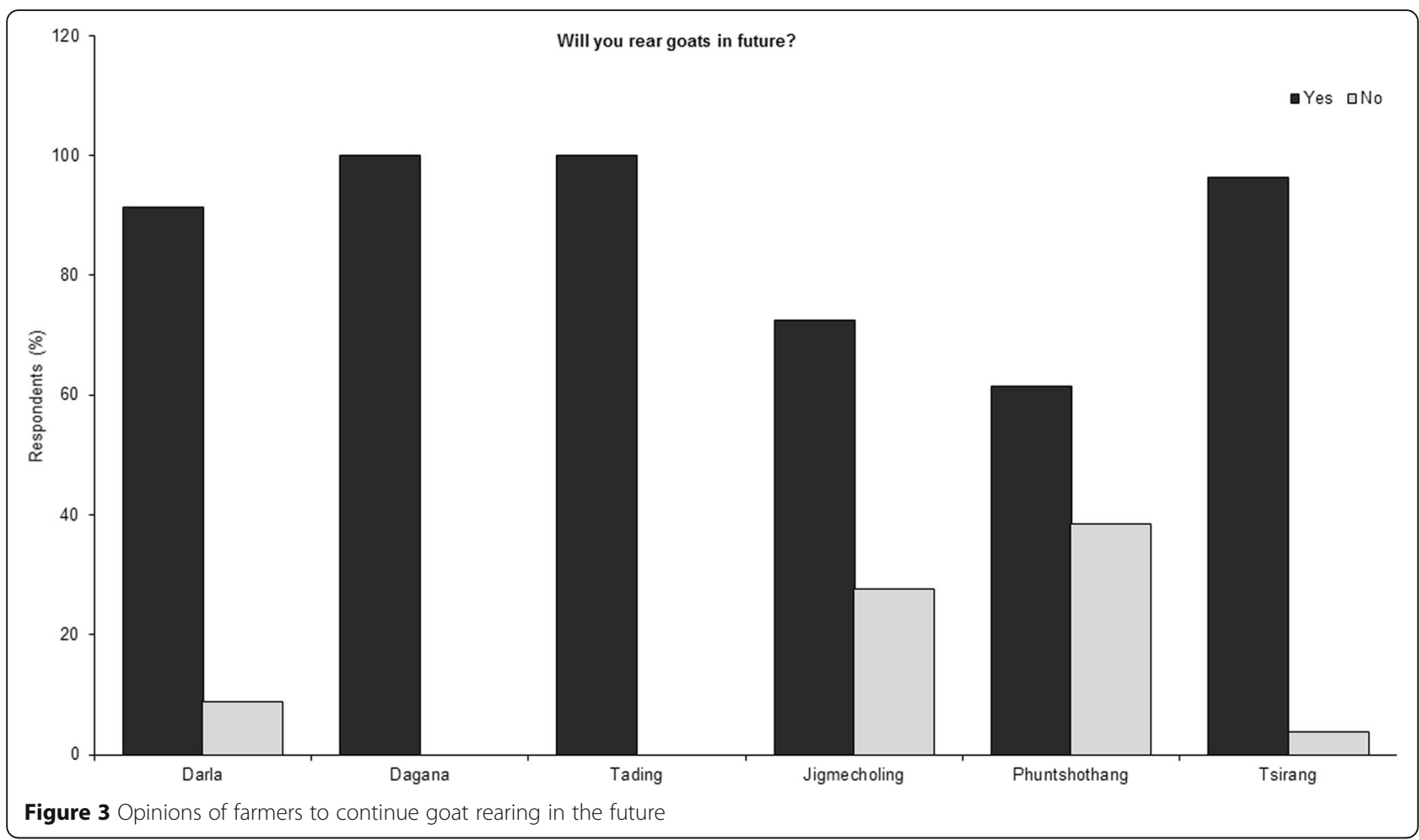

Despite the constraints, the great majority of surveyed farmers were in favour of continuing goat rearing in the future. Their view shows that goats have the potential to provide economic benefits to rural communities. This is because goats promise better income generation. Tamang et al. (2008) found in Bhutan that goats play an important economic role, with great potential to alleviate rural poverty. The other possible explanation is that goats have high prolificacy with average birth frequency of twice per year and average number of two kids per birth, and therefore, goats ensure faster economic returns (ICIMOD 2005; Tamang et al. 2008) and additionally, chevon (goat meat) fetching better price than other meat. Goats are ideally suited for the poorest farmers because of their short gestation

Table 5 Reasons for rearing goats in the future, according to farmers

\begin{tabular}{lccc}
\hline Study site & \multicolumn{3}{l}{ Respondents (\%) } \\
\cline { 2 - 4 } & Income generation & Manure production & $\begin{array}{c}\text { Less demand } \\
\text { for labour }\end{array}$ \\
\hline Darla & 59.1 & 22.7 & 10.5 \\
Dagana & 84.6 & 11.5 & 3.80 \\
Tading & 100.0 & 0.00 & 0.00 \\
Jigmecholing & 66.7 & 23.8 & 4.80 \\
Phuntshothang & 100.0 & 0.00 & 0.00 \\
Tsirang & 88.5 & 11.5 & 0.00 \\
\hline
\end{tabular}

period, low-risk capital investment, and low cost of maintenance (Gopala et al. 2010).

\section{Conclusions}

This study shows that the Forest and Nature Conservation Rule on goat rearing in Bhutan is largely natureoriented and overlooks the livelihoods of goat farmers. The conservation rule restricts farmers from earning more income and causes difficulties for farmers in managing goat population growth. The rule needs revision and should have a scientific basis when determining the number of goats which should be reared either under confinement with stall-feeding or free grazing. For effectiveness and general acceptance of the conservation rule, the revision process should actively involve livestock technocrats and experienced goat farmers. A better and shared understanding of cross-cutting issues would provide a common ground for both forest and livestock managers to pursue the changes that are needed in the rule. This may address equally the issues of nature conservation and farmers' livelihoods. Goat farmers have indigenous knowledge on goat rearing but are not aware of the modern and improved techniques and alternatives. Therefore, research and capacity building should be some of the future interventions in goat farming in Bhutan. Unlike in the past, the conservation rule on goat rearing must be reviewed routinely to accommodate the emerging needs of modern farming systems in the country. 


\section{Acknowledgements}

The authors gratefully acknowledge the financial supports of the Governments of Bhutan and India. We also thank Mr. Thinley Dorji, Mr. Durba Mongar, Mrs. Dechen Wangmo, and Ms. Ngawang Choden for their valuable assistance during the field surveys.

\section{Authors' contributions}

KW conceived the study, designed the survey, analysed the data, and wrote the paper. $\mathrm{M}, \mathrm{T}$, and SW assisted in designing and conducting the survey The co-authors also contributed to the writing of the paper. All authors read and approved the final manuscript.

\section{Authors' information}

Kesang Wangchuk is a Principal Research Officer at the Department of Livestock, Thimphu, Bhutan, and carries out research in social science and climate change. Mindu is a Research Officer at the National Highland Research and Development Centre, Bumthang, and conducts research in equine and poultry science. Thukten is a Livestock Production Officer at the District Livestock Office, Haa, and implements livestock development activities in the district. Sonam Wangchuk is a Program Director at the National Highland Research and Development Centre, Bumthang, and coordinates the highland livestock research and development programme in Bhutan.

\section{Competing interests}

The authors declare that they have no competing interests.

\section{Author details}

${ }^{1}$ Research and Extension Division, Department of Livestock, Ministry of Agriculture and Forests, Thimphu, Bhutan. ${ }^{2}$ National Highland Research and Development Centre, Department of Livestock, Ministry of Agriculture and Forests, Bumthang 32001, Bhutan. ${ }^{3}$ District Livestock Office, Department of Livestock, Ministry of Agriculture and Forests, Haa, Bhutan.

Received: 27 August 2016 Accepted: 17 September 2016

Published online: 07 November 2016

\section{References}

Bayne, P., R. Harden, and I. Davies. 2003. Feral goats (Capra hircus L.) in the Macleay River gorge system, north-eastern New South Wales, Australia. I. Impacts on soil erosion. Wildlife Research 31: 519-525.

Bird, K. 2008. The political economy of pro-poor growth. ODI Briefing Paper, no. 35. London: ODI.

Department of Livestock. 2015. Livestock Statistics 2015. Thimphu: Ministry of Agriculture and Forest.

Dorji, J. 1993. Estimation of grazing animal feed requirement in the Kingdom of Bhutan. National Environmental Commission, 2-17. Thimphu: Ministry of Agriculture.

Doyle, P.T., J.K. Egan, and A.J. Thalen. 1984. Intake, digestion, and nitrogen and sulfur retention in Angora goats and Merino sheep fed herbage diets. Australian Journal of Experimental Animal Husbandry 24: 165-169.

Gopala, G.T., K.C. Veeranna, and S.K. Radder. 2010. Constraints in goat farming in Bidar district of Karnataka state. Research Journal of Animal Husbandry Dairy Science 1: 80-82.

Henzell, R. 1993. The ecology of feral goats. In Proceedings of the National Workshop on Feral Goat Management: Planning for action, ed. D. Freudenberger, 9-16. Canberra: Bureau of Resource Sciences.

ICIMOD. 2005. Goat management and fish farming. Kathmandu: International Centre for Integrated Mountain Development (ICIMOD).

Jacoby, J., and M. Matell. 1971. Three-point Likert scales are good enough. Journal of Marketing Research 8: 495-500.

Jakobsen, J., K. Rasmussen, R. Folving, S. Leisz, and N.V. Quang. 2007. The effects of land tenure policy on rural livelihoods and food sufficiency in the upland village of Que, North Central Vietnam. Agricultural System 94: 309-319.

Landau, S., and B.S. Everitt. 2004. A handbook of statistical analyses using SPSS. Boca Raton: FL Chapman \& Hall/CRC.

Likert, R. 1932. A technique for the measurement of attitudes. Archives of Psychology 140: 1-55.

MoAF. 2006. The Forest and Nature Conservation Rules of Bhutan 2006. Department of Forest and Park Services. Thimphu: Ministry of Agriculture and Forests.

MoAF. 2010. Bhutan Land Cover Assessment 2010. Thimphu: Ministry of Agriculture and Forest.
Mukadasi, B., and B. Lusiba. 2006. Farmers' perception of the relevance of agricultural technologies under Plan for Modernization of Agriculture in Uganda. Ugandan Journal of Agriculture Science 12: 7-15.

Parkes, John, Robert Henzell, and Greg Pickles. 1996. Managing vertebrate pests: Feral goats. Canberra: Australian Government Publishing Service.

Rural Livelihood Project Phase 2014. Impact assessment of pro-poor policy interventions, 1-50. Thimphu: Rural Livelihood Project II.

Sparts, G., and D. Mueller-Dombois. 1973. The influence of feral goats on koa tree reproduction in Hawaii Volcanoes National Park. Ecology 54: 870-876.

Tamang, N.B., D.L. Sherpa, G. Tshering, G. Thinley, and B.N. Sharma. 2008. Goats in subtropical Bhutan: Poor farmer's choice to enhance livelihood. Bhutan RNR Journal 4(1): 97-106.

Vuren, D.V. 1992. Eradication of feral goats and sheep from island ecosystems. Proceedings of the Fifteenth Vertebrate Pest Conference 1992. New Zealand: University of Nebraska - Lincoln.

Wallner, A., N. Bauer, and M. Hunziker. 2007. Perceptions and evaluations of biosphere reserves by local residents in Switzerland and Ukraine. Landscape and Urban Planning 83: 104-114.

Wangchuk, K., M. Wurzinger, A. Darabant, G. Gratzer, and W. Zollitsch. 2014. The changing face of cattle raising and forest grazing in the Bhutan Himalaya. Mountain Research and Development 34: 131-138.

Wangdi, T., P. Lhendup, and N. Wangdi. 2013. An analysis of forestry policy, Acts and Rules of Bhutan to mainstream climate change adaptation. Regional Climate Change Adaptation Knowledge Platform for Asia, Partner Report Series No. 13. Bangkok: Stockholm Environment Institute. Available at http://www.asiapacificadapt.net or http://www.weADAPT.org. Accessed on 11 July 2016

Wilson, A.D., and W.E. Mulham. 1980. Vegetation changes and animal productivity under sheep and goat grazing on an arid belah (Casuarina cristata)rosewood (Heterodendrum oleifolium) woodland in western New South Wales. Australian Rangelands Journal 2: 183-188.

\section{Submit your manuscript to a SpringerOpen ${ }^{\circ}$ journal and benefit from:}

- Convenient online submission

- Rigorous peer review

- Immediate publication on acceptance

- Open access: articles freely available online

- High visibility within the field

- Retaining the copyright to your article

Submit your next manuscript at springeropen.com 